\title{
Analysis of engine particulate matter emission testing equipment
}

\author{
Ma Ru ${ }^{\mathrm{i} 1, \mathrm{a},}$ Yao Shengzhuo ${ }^{2, \mathrm{~b}}$ \\ ${ }^{1,2}$ School of Mechanical-electronic and Automobile Engineering, Beijing University of Civil Engineering and Architecture, Beijing 100044, \\ China \\ asilent_lan@sina.com, ${ }^{b}$ yaoshengzhuo@bucea.edu.cn
}

\begin{abstract}
As the engine emission of particulate matter(PM) pollution is taking attention by the people, the testing method about emission also need to be solved. In this paper, it starts from the principle of PM measurement, and introduce in detail the classification of various testing methods, in addition, this paper introduces the typical particulate matter testing equipment which has entered the stage of practical on the basis of principle, and analysis the measurement methods of these types of devices and their limitations. At the same time, emphasis the importance of the analysis of size distribution on particulate emission tests.
\end{abstract}

\section{INTRODUCTION}

With the advancement and development of national automobile technology, the concentration of particulate matter and quantity when drive a car has became the focus of attention. The reliance on car of many traffic developed cities in China is increasing gradually, automobile pollution problem has cropped up, according to the particle size to classify about the emissions of exhausting by engine, most belong to the submicron fine particles and ultrafine particles, since the size of these particles is extremely small, so it could easily enter the lung tissue of bodies, even into the blood and immune cells, that will cause the body's cardiovascular system diseases and immune response, also can induce cancer, and so on ${ }^{[1]}$. Therefore all countries' emission regulations control the emission of particles increasingly stringent. As shown in Table 1, The value of heavy vehicles decreased from $0.14 \mathrm{~g} / \mathrm{km}$ (Europe I) to $0.04 \mathrm{~g} / \mathrm{km}$ (Europe IV, 2006), while the light vehicle is dropped to $0.025 \mathrm{mg} / \mathrm{km}$.
Based on the above, in order to determine the actual vehicle particulate emissions ${ }^{[2,3]}$. It is important to design the reasonable test system.

Table.1. European diesel emission limits

\begin{tabular}{|c|c|c|c|c|c|c|c|}
\hline \multirow[t]{2}{*}{ Type } & \multirow{2}{*}{$\begin{array}{l}\text { Contr } \\
\text {-ol } \\
\text { Stage }\end{array}$} & \multirow{2}{*}{$\begin{array}{l}\text { Implem } \\
\text {-enting } \\
\text { Period }\end{array}$} & \multicolumn{5}{|c|}{ Emission Limit $(\mathrm{g} / \mathrm{km})$} \\
\hline & & & $\mathrm{CO}$ & $\begin{array}{l}\mathrm{HC}+ \\
\mathrm{NO}_{\mathrm{X}}\end{array}$ & $\begin{array}{l}\mathrm{H} \\
\mathrm{C}\end{array}$ & $\mathrm{NO}_{\mathrm{X}}$ & PM \\
\hline \multirow{5}{*}{$\begin{array}{l}\text { Diesel } \\
\text { Vehicle }\end{array}$} & $\begin{array}{l}\text { Euro- } \\
\text { pe I }\end{array}$ & 1994.10 & $\begin{array}{l}2.72 \\
5.17\end{array}$ & $\begin{array}{l}0.97 \\
1.40\end{array}$ & - & - & $\begin{array}{l}0.14 \\
0.19\end{array}$ \\
\hline & $\begin{array}{l}\text { Euro- } \\
\text { pe II }\end{array}$ & 1998.01 & $\begin{array}{l}1.00 \\
1.25\end{array}$ & $\begin{array}{l}0.70 \\
1.00\end{array}$ & - & - & $\begin{array}{l}0.08 \\
0.12\end{array}$ \\
\hline & $\begin{array}{l}\text { Euro- } \\
\text { pe III }\end{array}$ & $\begin{array}{l}2000.01 \\
2001.01 \\
2001.01\end{array}$ & $\begin{array}{l}0.64 \\
0.80 \\
0.95\end{array}$ & $\begin{array}{l}0.56 \\
0.72 \\
0.86\end{array}$ & - & $\begin{array}{l}0.50 \\
0.65 \\
0.78\end{array}$ & $\begin{array}{l}0.05 \\
0.07 \\
0.10\end{array}$ \\
\hline & $\begin{array}{l}\text { Euro- } \\
\text { pe IV }\end{array}$ & $\begin{array}{l}2005.01 \\
2006.01 \\
2006.01\end{array}$ & $\begin{array}{l}0.50 \\
0.63 \\
0.74\end{array}$ & $\begin{array}{l}0.30 \\
0.39 \\
0.46\end{array}$ & - & $\begin{array}{l}0.25 \\
0.33 \\
0.39\end{array}$ & $\begin{array}{l}0.025 \\
0.04 \\
0.06\end{array}$ \\
\hline & $\begin{array}{l}\text { Euro- } \\
\text { pe V }\end{array}$ & 2008.06 & $\begin{array}{l}0.50 \\
0.63 \\
0.74\end{array}$ & $\begin{array}{l}0.25 \\
0.32 \\
0.38\end{array}$ & - & $\begin{array}{l}0.20 \\
0.26 \\
0.31\end{array}$ & $\begin{array}{l}0.005 \\
0.005 \\
0.005\end{array}$ \\
\hline
\end{tabular}




\section{ANALYSIS OF PRINCIPLE AND CHARACTERISTIC OF PARTICULATE TESTING EQUIPMENT}

At present there are not many specialized particle testing equipment, and most of these are used to measure the particle size. According to the principle, it can be divided into several categories, Each instrument is to use some properties related to the particle size, such as electric mobility, aerodynamic diameter, optical properties, migration of inertia force, photoelectric, mass spectrometry, etc. Researchers can use these instruments to get some informations about the particle size, in addition, as these instruments use different principle to measure, it leads to the result of measurement cannot be compared directly. as a general rule, it is impossible to receive $0.01 \sim 100 \mu \mathrm{m}$ particle size distribution with the same instrument in the range of $10^{-5}$. Here are introduced some kinds of typical instru.

\subsection{ELPI(Electrical Low Pressure Impactor) ${ }^{[2,4,5,6]}$}

The testing equipment ELPI which is produced by Finland DEKATI can test vehicles in real-time, the range of Particle distribution and concentration is $7 \mathrm{~nm}$ to $10 \mu \mathrm{m}$. It can be calculated the quality of the transient emissions when obtaining the transient exhaust flow.

\subsubsection{System Composition}

System as shown in figure 1 , including inlet, charging chamber the low-pressure impactor vent, and control panel.

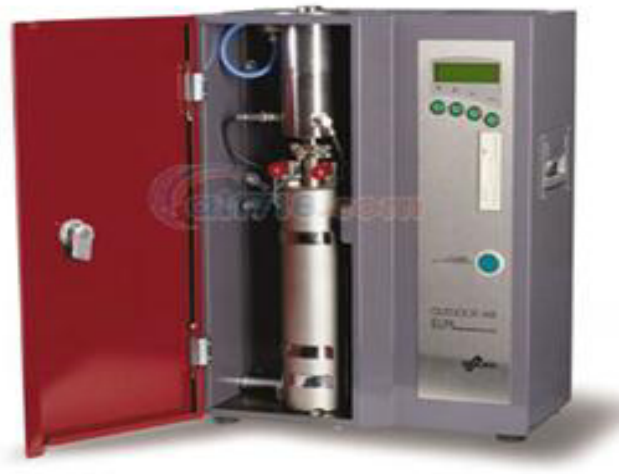

\subsubsection{Working Principle}

Before enter the ELPI, the sample of gas which contain particles firstly fix ratio (1:8 or $1: 64)$ to dilution with dry air which is provided by air compressor-The single stage dilution and two levels of dilution, let the sample introduces into the ELPI inlet channel, and then pass into a unipolar corona charging room to charge, the charged particles will be shipped to a low pressure impact which has Insulating layer to collect.

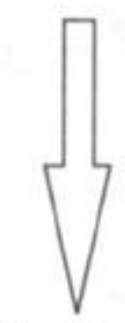

Flow direction

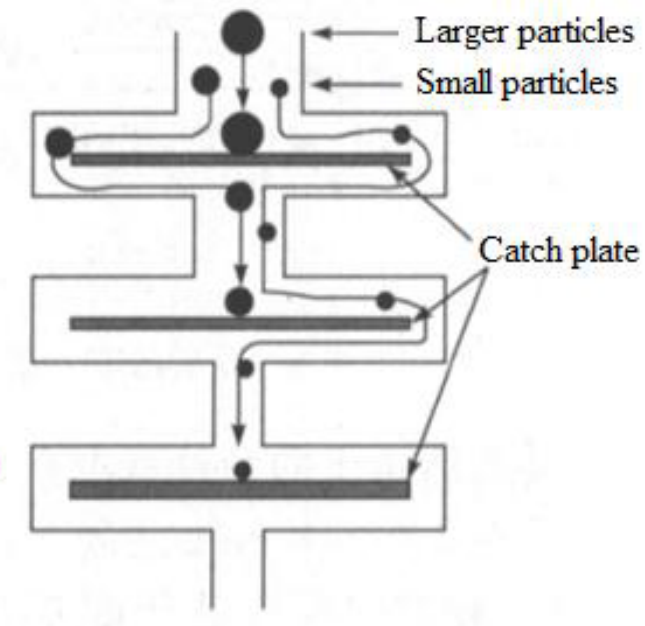

Fig 2. The collecting principle of impactor

The particles in each layer of the impactor catch plate is based on the aerodynamic characteristics, it using charge room features and depending on impacting the particle size on a layer, and convert the current to the particle size distribution. Low impact includes several levels, When the gas in each level, the charged particles with the flow air in motion, as there are different sizes of the particles, larger particles will be impacted to a certain level of low pressure impact due to inertia effect. Therefore, the charged particles of different level with different quality, and it realize the classification of particles.

The charged particles generate an electric current when impact at all levels, it can be measured electricity through a precision multi-channel electrometer, The standard RS232 port is provide communication interface for laptop or PC, the current value of each channel is proportional to the number of particles collected, so it is also proportional to the particles concentration in a certain size of the particles scope.

Fig 1. The structure diagram of ELPI 


\subsubsection{The test data and its application}

In the experiment ELPI can record the particulate emissions in whole condition, the sampling frequency is 1 $\mathrm{Hz}$, it meas once per second, it is classified 12 levels for the raw data of current value. In addition, ELPI can also get the number of real-time exhaust particulate matter concentrations, mass concentration, particle size distribution and other important information. The biggest characteristic is to classify detailedly for the particulate matter in accordance with the quality and size, this method is too detail to reach when we use the filter paper in the laboratory. In this way, we can do some in-depth analysis, and research the factor which affect vehicle emissions.

\subsection{Electric mobility particle analyzer}

The core component of this kind of instrument is a electric mobility detector, the instruments such as EAA, DMPS, SMPS, nano-DMA belong to this category, the SMPS (sequential mobility particle sizer) is most widely used, next let introduce the SMPS $+\mathrm{C}$ systems of the GRIMM company in United States ${ }^{[4]}$.

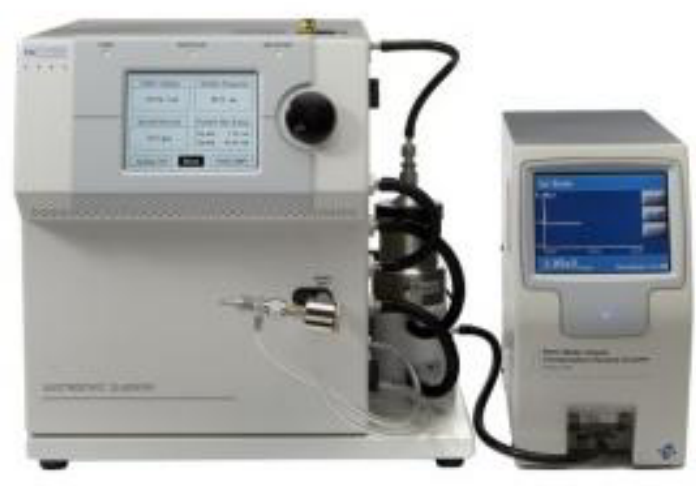

Fig. 3 The structure diagram of SMPS

\subsubsection{Working Principle}

At first, making the particles to be charged through the charge electric appliance, there is a certain relationship between the particles charge and size, and then the charged particles through the area of variable electric field, under the action of electric field intensity, this area can make the charged particles which meet a certain electrical mobility sedimentation to the wall. By measuring the current size, the number of particles which in the range of corresponding electric mobility can be calculated, and by changing the electric field intensity can change the range of the particle size.

\subsubsection{The test data and its application}

The data measuring range of SMPS $+\mathrm{C}$ system is less than $1 \mu \mathrm{m}$, its lower limit can be reached 7 10 nm, the number of particles can reach 107/L, and the nano-DMA can analyze 3 50 nm particles size distribution, but there is no commodity products to choose, this species of instruments suit to measure the particle distribution in the diesel engine because it have a lot of particles size ranges, due to the time of measurement is between $10 \mathrm{~s}$ to $60 \mathrm{~s}$, it is not suit for dynamic measurement, But the main advantage is the high resolution, that correspond to the ELPI.

\subsection{Other testing equipment}

In addition to the above two kinds of instruments, there are some measuring instruments, such as mass spectrometer, radioactive tracer and photoelectric effect particle analyzer, etc. Mass spectrometer is applied to analyze particle composition in the past, general particles release or ionize after laser excitation, and then it will be measured by mass spectrometer, which reflect the chemical composition of the particles ${ }^{[7]}$. The advantages of mass spectrometer is that can give a single chemical components rather than the content of total PAH(polycyclic aromatic hydrocarbons), ATOMFS, on-line Aerosol MassSpectrometer, PBMS and so on are all such instruments. The particles size range of this kind of instrument can reach from tens of microns to a few tenths of microns. Radioactive tracer can measure radioactivity relate to the particles surface, this kind of instrument has Epiphaniometer. photoelectric effect particle analyzer can measure the total number of particles which carry PAH in real-time, And provides a measurement method of PAH. PAS uses this kind of principle, the instrument can measure the total surface area of particles. 


\section{PROBLEMS AND FUTURE TO PARTICLE DETECTING}

With the development of the modern engine technology, particulate emissions reduces significantly in terms of absolute quality, but with the deepening of the medical research, scientists found that particle emissions of Nanoscale harm to human body badly. And the testing data indicates that modern engine technology of controlling particulate emissions has a tendency to increase the number of nanoscale particles, so the method of anlayzing engine particle size distribution and quantity can research the harm of particles deeply. These devices which have introduced can be realized in a certain range of particle size classification, but to measure accurately, there are many conditions will be limited strictly, so the test process are still in research stage. With the engine-related technology research and medicine for its role in promoting, in the future restrictions on particulate emissions will be the same as gas emissions, and into an era of quantitative control and reduce gradually, finally, it will make the car serve for human being on the premise of more environmentally friendly.

\section{References}

[1] Dong Gang, CHAN Tat Leung. Particle Number and Size Distributions along the Vehicular Exhaust Plume from a Light-Duty Diesel Vehicle[J]. In Chinese. Transaction of CSICE, 1st edn. 2012.6.

[2] Sun Zhichun. Research on the micro particulate matter emissions for vehicles[D]. In Chinese. Chang'an. Chang'an University. 2013.6.

[3] Guo Hejun. Development of Gasoline Detergent Additive Research[J]. In Chinese. Polymer Material Science and Engineering. 2012. 18(1): 171-175.

[4] Chen Long. Test Method of Engine Particulate Emissions[J]. In Chinese. Urban Vehicle Technology and Research. 2009.8.

[5] Knecht W. Diesel Engine Development in View of Reduced Emission Standards[J]. Energy, 2008, 33(2): 264-271.

[6] Gupta T, Kothari A, Srivastava DK, et al. Measurement of number and size distribution of particles emitted from a mid-sized transportation multipoint port fuel injection gasoline engine[J]. Fuel. 2010, 89(9): 2230-2233.
[7] Liu Shuangxi, Gao Junhua. Experimental Study on Exhaust Particles from Light Duty Gasoline Vehicle[J]. In Chinese. Small Internal Combustion Engine and Motorcycle. 2009.12. 